\title{
Myxobolus saladensis sp. nov., a new species of gill parasite of Mugil liza (Osteichthyes, Mugilidae) from Samborombón Bay, Buenos Aires, Argentina
}

\author{
Paula Marcotegui \& Sergio Martorelli
}

Centro de Estudios Parasitológicos y Vectores (CCT-La Plata), Boulevard 120 s/n entre av. 60 y calle 64 (1900) La Plata, Buenos Aires, Argentina.

Received 25 May 2016

Accepted 10 August 2016

DOI: $10.1590 / 1678-4766 e 2017026$

\begin{abstract}
Myxosporean Myxobolus saladensis sp. nov. in the gills of Mugil liza Valenciennes, 1836 from Samborombón Bay was described by light and electron microscopy studies. Spores were pyriform and binucleated, measuring $10.63 \pm 0.36 \mu \mathrm{m}(\mathrm{n}=20) \mathrm{long}, 9.24 \pm 0.50 \mu \mathrm{m}(\mathrm{n}=20) \mathrm{wide}$ and $4.13 \pm 0.36$ $\mu \mathrm{m}(\mathrm{n}=20)$ thick, included in polysporic cyst-like plasmodia. Elongated pyriform polar capsules were of equal size $(3.84 \pm 0.27 \mu \mathrm{m}$ long and $2.30 \pm 0.12$ $\mu \mathrm{m}$ wide). The sporoplasm contained some sporoplasmosomes. Each PC contained a polar filament with 4-5 coils obliquely arranged in relation to the polar capsules axis. The PC wall was composed of two layers of different electron densities. Based on the morphological and ultrastructure differences of the spore to those of previously described species of Myxobolus, we describe a new species, Myxobolus saladensis sp. nov.
\end{abstract}

KEYWORDS. Myxosporean, mullets, Myxobolidae, gills parasites.

Members of Myxobolus Biitschli, 1882 are considered cosmopolitan, with many species cited in mullets. According to ZATTI et al. (2015) approximately 90 myxosporean species have been identified in South America, of which 41 are from the this genus, mostly from Brazil (EIRAS et al., 2010; AzEvEDo et al., 2010; 2011; 2012). Mullets live in shallow and brackish waters and are euryhaline, ranging from hypersaline lagoons to freshwater. They utilize estuarine nursery habitats where they feed largely on plant material obtained by grubbing through bottom detritus (CERVIGÓN et al., 1993).

The Mugilidae is represented by three species along the coast of the Southwest Atlantic Ocean (CoussEAu et al., 2005). In Argentine waters, the only mullet permanently present is the grey mullet Mugil liza Valenciennes, 1836 (see COUSSEAU et al., 2005) after synonymization of Mugil platanus Günther, 1880 with M. liza (HerAs et al., 2009). This species is commercially exploited in Brazil and Argentina by inshore artisanal fisheries.

Helminths parasitizing M. liza have been reported by many authors in the last years (KNOFF \& AMATO, 1992; KoHn et al., 1994; KNOFF et al., 1997; SuRIANO et al., 2000; Carnevia \& Speranza, 2003; AbDallah et al., 2009; Marcotegui \& Marcotelli, 2009a,b; Siquier \& Ostrowski de NuÑEz, 2009; Alarcos \& ETCHEGOIN, 2010; MARCOTELLI et al., 2012). However, gill Myxozoa have not been reported from this host. EIRAS et al. (2007) recorded Myxobolus platanus Eiras et al., 2007 parasitizing pancreatic tissue of Mugil platanus in Lagoa dos Patos, Brazil.
In a survey of fish parasites in estuarine areas of Argentina a new myxosporidian species was found in Mugil liza collected from Samborombón Bay. A light and electron microscopic study on the new species is presented.

\section{MATERIALS AND METHODS}

A total of 206 specimens of Mugil liza (Valenciennes, 1836) (Mugilidae) were captured between April 2006 and April 2009. These specimens ranging in total length from 2.8 to $32.0 \mathrm{~cm}$ and total weight from $0.22-331.41 \mathrm{~g}$ were captured from the mouth of the Canal Aliviador of Salado River (35'50’12.53”'S, 57²5’22.28”W, Samborombón Bay, Buenos Aires, Argentina) and examined for parasites. Live fish were transported to the laboratory in containers filled with estuarine water and were kept alive in oxygenated aquaria until examination. Skin, fins, excised gills, and intestinal tract from newly killed fishes were analyzed under a dissecting microscope to detect parasites.

Plasmodium (Pmd) containing numerous spores were found in the gill filaments and gill rakers (Fig. 1). The gills infected were observed by DIC microscopy for fresh spore measurements. For ultrastructural studies, fragments of gills infected were excised and fixed in 2.5\% Glutaraldehyde in $0.2 \mathrm{M}$ Sodium Cacodylate buffer ( $\mathrm{pH} 7.2$ ) for $12 \mathrm{~h}$ at $4^{\circ} \mathrm{C}$, washed in the same buffer $12 \mathrm{~h}$ at $4^{\circ} \mathrm{C}$ and post fixed in $2 \%$ $\mathrm{OsO}_{4}$ buffered with the same solution for $4 \mathrm{~h}$ at the same temperature. Ultrathin sections were observed in a JEOL 1200EX II TEM (JEOL Optical, Tokyo, Japan). 
The dimensions of the spores (in $\mu \mathrm{m}$ ) were expressed as the mean \pm standard deviation. Length and width of spores were obtained from 20 fresh specimens. Thickness were obtained from 20 additional spores. Measurements of polar capsules length and width of the spores were obtained from ultrathin serial sections. All measurements were taken from microphotographs using Image J software (National Institutes of Health).

\section{RESULTS}

\section{Myxobolus saladensis sp. nov.}

(Figs 1-7)

urn:lsid:zoobank.org:act:51F1772D-C806-4B52-9A59CB70F10D47A5
Diagnosis. Spherical Pmd containing numerous spores located in the gill filaments and rakers. Pyriform fresh spores tapering anteriorly $10.63 \pm 0.36$ (range 10.05 11.13) $\mu \mathrm{m}$ long, $9.24 \pm 0.50$ (range 8.42-9.79) $\mu \mathrm{m}$ wide, and $4.13 \pm 0.36$ (range $2,65-4,9) \mu \mathrm{m}$ thick. Two equal-sized pyriform PC measuring $3.84 \pm 0.27$ (range 3.33-4.03) $\mu \mathrm{m}$ long and $2.30 \pm 0.12(2.14-2.43) \mu \mathrm{m}$ wide. Polar filament coiled in four or five turns.

Site of infection: spores located in epithelium of gill rakers.

Etymology. The specific epithet refers to the type locality, Salado River.

Type material. One glass slide with semithin sections of the cyst containing spores (Hapantotype) was deposited in the Museo de La Plata collection, number MLP-Pr-095.
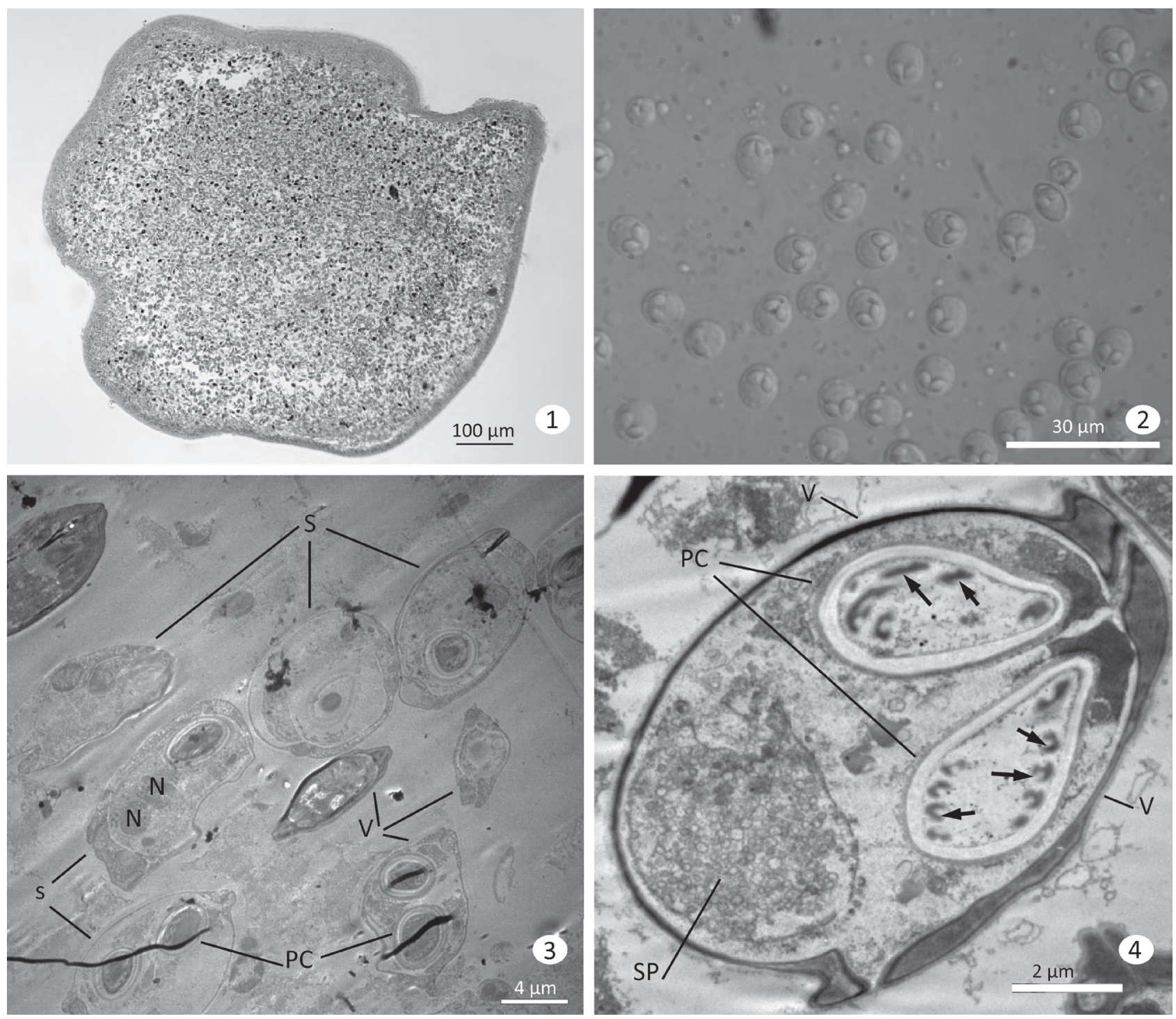

Figs 1-4. Light and transmission electron micrographs of the myxosporean Myxobolus saladensis sp. nov. infecting gills and gills rakers of Mugil liza Valenciennes, 1836: 1, semithin section of a plasmodium; 2, isolated spores observed in differential interference-contrast (DIC); 3, ultrathin section of a plasmodium showing several spores at different levels (S); 4, sectioned spore showing the shell valves (V); polar capsules (PC); Sporoplasm (SP) and transverse section of the polar filament (arrows). 

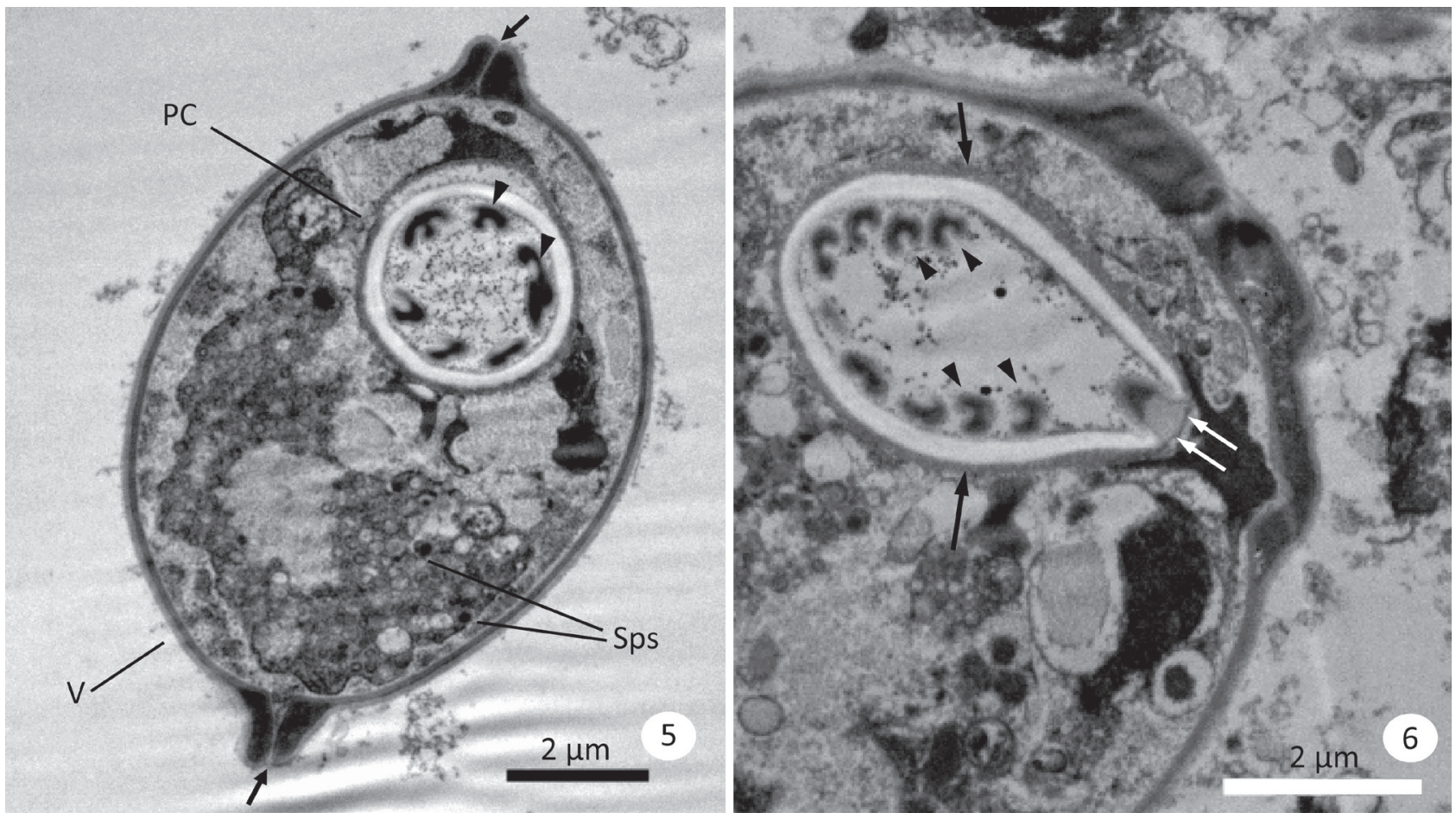

Figs 5, 6. Myxobolus saladensis sp. nov. parasite of Mugil liza Valenciennes, 1836: 5, sectioned spore showing valves (V) and their suture lines (arrows), polar capsules (PC), different sections of the polar filaments (arrowheads) and some sporoplasmosomes (Sps); 6, detail of apical region of the PCs showing the PC wall (arrows) composed of two layers and the apical stopper (double arrows) and the different sections of the polar filament (arrowheads).

Type Locality. Salado River, Samborombón Bay, Buenos Aires, Argentina.

Type Host: Mugil liza.

Prevalence: $12.7 \%$.

Description. Spores typical of Myxobolus Bütschli, 1882 , rounded in valvular view and biconvex in sutural view, shell valves smooth and without projections. Fresh mature spores pyriform in shape (Fig. 2). Mean spore measurements \pm standard deviations as follows: $10.63 \pm 0.36$ (range 10.05-11.13) long, 9.24 \pm 0.50 (range 8.42-9.79) wide, and $4.13 \pm 0.36$ (range 2.65-4.91) thick. Spore wall thin and smooth comprising two symmetrical and equal shell valves adhering together along the prominent longitudinal sutural line (Figs 3-6). Internally, two equal and elongated pyriform polar capsules (PCs), located side by side at the same level, measured 3.84 \pm 0.27 (range 3.33-4.03) long, 2.30 \pm 0.12 (range 2.14-2.43) wide (Figs 3-6). Intercapsular appendix not observed. Inside the PCs, polar filament coil displayed four or five slightly oblique to the longitudinal axis (Fig. 6). Apical end of the PCs contained a circular stopper formed by electron-lucent material (Fig. 6). At the posterior pole of the spore, a binucleated sporoplasm contained numerous light vesicles, numerous sporoplasmosomes (Figs 4, 5).

Nuclei located at the same level, contained uniform chromatin without evident nucleoli (Fig. 3). A schematic drawing of spore morphology (Fig. 7) shows the arrangements of the different structures and organelles.

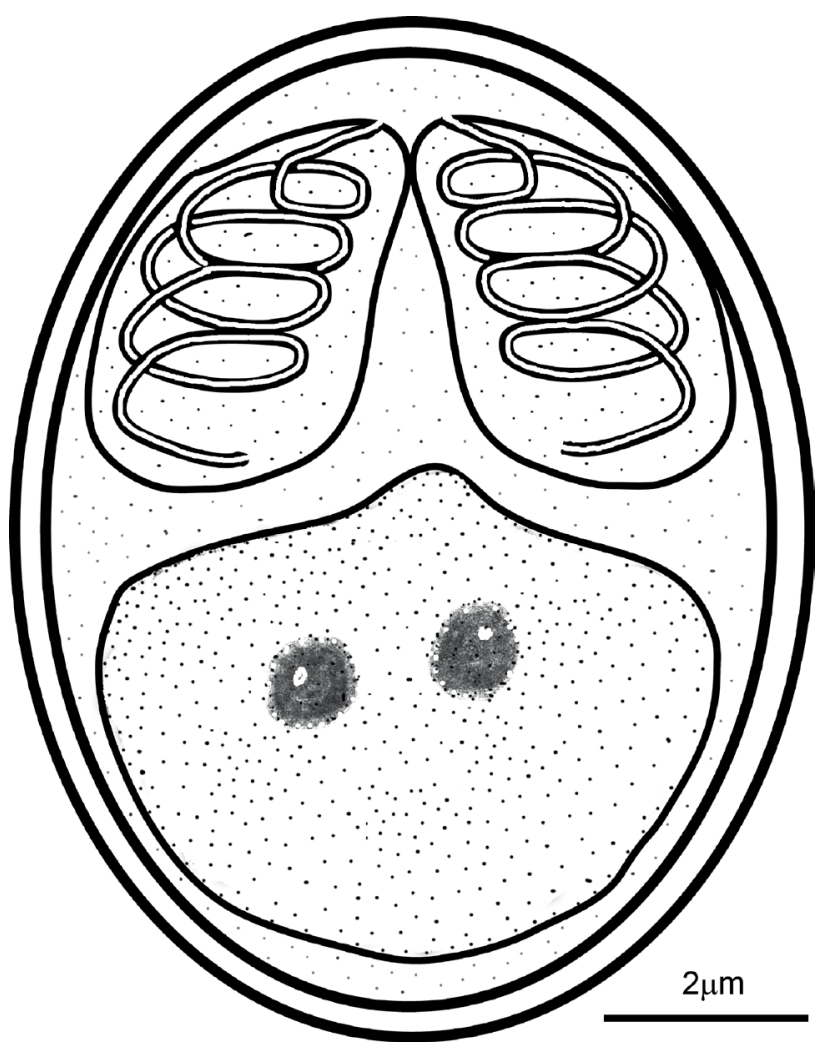

Fig. 7. Schematic drawing of the morphology of a spore of Myxobolus saladensis sp. nov. witch infects Mugil liza Valenciennes, 1836 from Argentina. 
Tab. I. Comparative measurement (in $\mu \mathrm{m}$ ) of the spores from Myxobolus spp. parasiting mugilid fishes which resembles the new species (SL, spore length; SW, spore width; PCL, polar capsules length; PCW, polar capsules width; NC, number of coils on the polar filament).

\begin{tabular}{|c|c|c|c|c|c|c|c|}
\hline Species & SL & SW & PCL & PCW & $\mathrm{NC}$ & Organ & Host species \\
\hline M. chiungchowensis & $10.2-11.8$ & $9.6-11$ & $5.6-6.2$ & $3.4-3.8$ & $6-8$ & Intestine & Mugil cephalus \\
\hline M. goensis & $9.5-10.5$ & $6-7.5$ & $4.5-6$ & $2-3$ & 5 & Gills archs & Mugil cephalus \\
\hline M. goreensis & $10-13$ & $10-13$ & $4-5$ & $2-4$ & - & Gills & Mugil cephalus \\
\hline M. mugilii & $8.1-16.3$ & $4-7.3$ & $2.4-8.1$ & $1.6-4$ & - & Gills & Mugil cephalus \\
\hline M. rohdei & $9.8-11.8$ & $8.4-9.1$ & $3.7-5$ & $2.5-3.1$ & $3-4$ & Kidneys & Mugil cephalus \\
\hline M. spinacurvatura & $10.5-12.5$ & $9-11$ & $3.5-5$ & $2.5-3.5$ & - & Mesentery, brain, spleen & Mugil cephalus \\
\hline M. platanus & $10-11$ & $10-11$ & $7-8$ & $3.5-4$ & - & Spleen & Mugil platanus \\
\hline M. galaxii & $13-15$ & $8.8-10$ & - & - & - & All organs except gills & Galaxias maculatus \\
\hline M. magellanicus & $11.9 \pm 0.6$ & $12.9 \pm 0.5$ & 3 & - & - & Gills & Galaxias maculatus \\
\hline M. paranensis & $12-15$ & $7-8$ & $6-7$ & 2.5 & - & Gonads & Salminus maxillosus \\
\hline M. saladensis sp. n. & $10.05 \pm 11.13$ & $8.42-9.79$ & $3.33-4.03$ & $2.14-2.43$ & $4-5$ & Gills & Mugil liza \\
\hline
\end{tabular}

\section{DISCUSSION}

Of the Myxobolus species described from mullet, those analyzed during the present study resemble $M$. chiungchowensis Chen, 1998, M. goensis Eiras \& D'Souza, 2004, M. goreensis Fall et al., 1977, M. mugilii Haldar et al., 1996, M. rohdei Lom \& Dykova, 1994, and M. spinacurvatura Maeno et al., 1990 from the size of spores. Nevertheless the new species proposed can be distinguished from M. chiungchowensis, M. goensis, $M$. goreensis, and M. mugilii, by having smaller size of the polar capsules, and M. spinacurvatura and M. rohdei by the number of turns of the filament polar capsules (see Tab. I).

EIRAS et al. (2007) reported Myxobolus platanus parasitizing pancreatic tissue of Mugil platanus (actually $M$. liza) in Lagoa dos Patos, Brazil. The new species differs from M. platanus by having smaller polar capsules not exceeding half the length of the spore (see Tab. I). Furthermore, the infection site (pancreatic tissue) of the parasite described by EIRAS et al. (2007) differs from that of M. saladensis sp. nov., which infects gill rakers in M. liza.

In Argentina M. galaxii Szidat, 1953 and $M$. magellanicus Szidat, 1953 (Flores \& Viozzi, 2001) have been reported from Galaxias maculatus Jenyns, 1842, and M. paranensis from Salminus maxillosus Bonetto \& Pignalberi, 1965. The specimens studied can be distinguished from those species by having smaller spores (Tab. I). Additionally, Viozzi (1996) has reported Myxobolus sp. from Percichthys trucha Valenciennes, 1833, Galaxias maculatus and Hatcheria macraei Girard, 1855 in Patagonian lakes, and SARDELla et al. (1998) reported Myxobolus sp. from Genypterus brasiliensis Regan, 1903 in Argentine Sea. In both reports, a formal description has not been undertaken, preventing a thorough comparison with the specimens found during this study.

According to Molnar (2002) knowledge of the actual site of establishment of the parasite in the gill may also facilitate the identification of parasite species; therefore, indicating the precise location of plasmodium development is indispensable for species descriptions. Host and organ specificity and tissue tropism should be considered in species identification (LIU et al., 2013). The new species plasmodium was found, in the epithelium of the gills rakers of all infected fish. The site of the plasmodium coincides with infections of the gill arch epithelium according to the typical localization of the plasmodium given by MOLNAR (2002).

Some gills Myxobolus species have been reported as pathogenic to fish (CAMUS \& GRIFFIN, 2010; Milanin et al., 2010; LiU et al., 2013). Heavy infections of myxozoan in gill lamellae, gills filaments or blood vessels of the gill arch, could produce severe gill changes affecting gas exchange. Although the new species is located in the epithelium of rakers this could affect the respiratory flow.

This is the second report of the genus Myxobolus from Mugil liza, and the fifth record of this genus in Argentina.

Acknowledgments. This work was funded by a fellowship grant from Consejo Nacional de Investigaciones Científicas y Tecnológicas (CONICET) to P. S. Marcotegui, and a research grant from Universidad Nacional de La Plata (UNLP: N504) to S. R. Martorelli.

\section{REFERENCES}

Abdallah, V. D.; Azevedo, R. K. \& Luque, J. L. 2009. Four new species of Ligophorus (Monogenea: Dactylogyridae) parasitic on Mugil liza (Actinopterygii: Mugilidae) from Guandu River, Southeastern Brazil. Journal of Parasitology 95:855-864.

Alarcos, A. J. \& Etchegoin J. A. 2010. Parasite assemblages of estuarine dependent marine fishes from Mar Chiquita coastal lagoon (Buenos Aires Province, Argentina. Parasitology Research 107:1083-91.

Azevedo, C.; Casal, G.; Mendonça, I.; Carvalho, E.; Matos, P. \& Matos, E. 2010. Light and electron microscopy of Myxobolus sciades n. sp. (Myxozoa), a parasite of the gills of the Brazilian fish Sciades herzbergii (Block, 1794) (Teleostei: Ariidae). Memórias do Instituto Oswaldo Cruz 105(2):203-207.

Azevedo, C.; Casal, G.; Marques, D.; Silva, E. \& Matos, E. 2011. Ultrastructure of Myxobolus brycon n. sp. (Phylum Myxozoa), parasite of the piraputanga fish Brycon hillari (Teleostei) from Pantanal (Brazil). Journal of Eukaryotic Microbiology 58:88-93.

Azevedo, C.; São Clemente, S. C.; Casal, G.; Matos, P.; Alves, A.; AlQuraishy, S. \& Matos, E. 2012. Myxobolus myleus n. sp. infecting the bile of the Amazonian freshwater fish Myleus rubripinnis (Teleostei: Serrasalmidae): morphology and pathology. Systematic Parasitology 82(3):241-247.

Camus, A. C. \& Griffin, M. 2010. Molecular Characterization and Histopathology of Myxobolus koi infecting the Gills of a Koi, Cyprinus carpio, with an Amended Morphological Description of the Agent. Journal of Parasitology 96(1):116-124 
Carnevia, D. \& Speranz, G. 2003. Seasonal variations in parasites found in mullet (Mugil platanus Günther, 1880) juveniles captured on the Uruguayan coast of the River Plate. Bulletin European Association of Fish Pathologists 23:245-249.

Cervigón, F. 1993. Los peces marinos de Venezuela. Caracas, Fundación Científica los Roques, vol. 2. 425p.

Chen, Q. L. \& Ma, C. L. 1998. Myxozoa, Myxosporea. Fauna Sinica. Beijing, Science Press, p. 292-528.

Cousseau, M.; González Castro, M.; Figueroa, D. \& Gosztonyi, A. 2005. Does Mugil liza Valenciennes 1836 (Teleostei: Mugiliformes) occur in Argentinean waters? Revista de Biología Marina y Oceanografía 40:133-140.

Eiras, J. C.; Abreu, P. C.; Robaldo, R. \& Pereira JR., J. 2007. Myxobolus platanus n. sp. (Myxosporea, Myxobolidae), a parasite of Mugil platanus Günther, 1880 (Osteichthyes, Mugilidae) from Lagoa do Patos, RS, Brazil. Arquivo Brasileiro de Medicina Veterinária e Zootecnia 59:895-898.

EIRAs, J. C. \& D'SouzA, J. 2004. Myxobolus goensis n. sp. (Myxozoa: Myxosporea: Myxobolidae), a parasite of the gills of Mugil cephalus (Osteichthyes, Mugilidae) from Goa, India. Parasite 11:243-248.

Eiras, J.; Monteiro, C. M. \& Brasil-Sato, M. C. 2010. Myxobolus franciscoi sp. nov. (Myxozoa: Myxosporea: Myxobolidae), a parasite of Prochilodus argenteus (Actinopterygii: Prochilodontidae) from the Upper São Francisco River, Brazil, with a revision of Myxobolus spp. from South America. Zoologia 27(1):131-137.

Fall, M.; Kpatcha, T. K. \& Diebakate, C. 1977. Observations sur des myxosporidies (Myxozoa) du genre Myxobolus parasites de Mugil cephalus (Poisson, Téléostéen) du Sénégal. Parasite 2:173-180.

Flores, V. \& Viozzi, G. 2001. Myxobolus magellanicus in Galaxias maculatus. Seasonality, host-parasite relationship and distribution in Patagonian Andean lakes (Argentina). Acta Parasitologica 46:159-163.

Haldar, D. P.; Samal, K. K. \& Mukhopadhyaya, D. 1996. Studies on the protozoan parasites of fishes in Orissa: eight species of Myxobolus Bütschli (Myxozoa: Bivalvulida). Journal of the Bengal Natural History Society 16:3-24.

Heras, S.; Roldán, M. \& González Castro, M. 2009. Molecular phylogeny of Mugilidae fishes revised. Reviews in Fish Biology and Fisheries 19:217-231.

Knoff, M. \& Amato, J. F. R. 1992. Nova especie do genero Phyllodistomum Braun, 1899 (Gorgoderidae, Gorgoderinae) parasita de tainha, Mugil platanus Günther, 1880 da costa do estado do Rio de Janeiro, Brasil. Revista Brasileira de Biologia 52:51-56.

Knoff, M.; Luque, J. L. \& Amato, J. F. R. 1997. Community ecology of the metazoan parasites of grey mullets, Mugil platanus (Ostheichthyes: Mugilidae) from the litoral of the state of Rio de Janeiro, Brazil. Revista Brasileira de Biologia 57:441-454.

Kohn, A.; Cohen, S. C. \& Baptista-Farias, M. De F. D. 1994. A redescription of the morphology of Metamicrocotyla macracantha (Alexander, 1954) Koratha, 1955 (Monogenea, Microcotylidae) from
Mugil liza in Brazil. Systematic Parasitology 27:127-132.

Liu, Y.; Whipps, C. M.; GU, Z. M.; Huang, M. J.; He, C.; YANG, H. L. \& Molnár, K. 2013. Myxobolus musseliusae (Myxozoa: Myxobolidae) from the gills of common carp Cyprinus carpio and revision of Myxobolus dispar recorded in China. Parasitology Research 112:289-296.

Lom, J. \& DyKovÁ, I. 1994. Studies on protozoan parasites of Australian fishes. 3. Species of the genus Myxobolus Bütschli, 1882. European Journal of Protistology 30:431-439.

Maeno, Y.; Sorimachi, M.; Ogawa, K. \& Egusa, S. 1990. Myxobolus spinacurvatura sp. n. (Myxosporea: Bivalvulida) parasitic in deformed mullet, Mugil cephalus. Fish Pathology 25:37-41.

Marcotegui, P. S. \& Martorelli, S. R. 2009a. Ligophorus saladensis n. sp. (Monogenea: Acyrocephalidae) from Mugil platanus Günther in Samborombon Bay, Argentina. Systematic Parasitology 74:41-47.

Marcotegui, P. S. \& Martorelli, S. R. 2009b. Trichodinis (Ciliophora: Peritrichida) of Mugil platanus (Mugiliformes: Mugilidae) and Micropogonias furnieri (Perciformes: Sciaenidae) from Samborombon Bay, Argentina with the description of a new species. Folia Parasitologica 56:167-172.

Martorelli, S. R.; Lino, A.; Marcotegui, P.; Montes, M. M.; Alda, P. \& PANEI, C. J. 2012. Morphological and molecular identification of the fish-borne metacercaria of Ascocotyle (Phagicola) longa Ransom, 1920 in Mugil liza from Argentina. Veterinary Parasitology 190:599-603.

Milanin, T.; Eiras, J.; Arana, S.; Maia, A.; Alves, A.; Silva, M.; Carriero, M.; Paulo, S.; Ceccarelli, P. \& Adriano, E. 2010. Phylogeny, ultrastructure, histopathology and prevalence of Myxobolus oliveirai sp. nov., a parasite of Brycon hilarii (Characidae) in the Pantanal wetland, Brazil. Memórias do Instituto Oswaldo Cruz 105:762-769.

Molnar, K. 2002. Site preference of fish myxosporeans in the gill. Disease Aquatic Organisms 48:197-207.

Sardella, N. H.; Avendaño, M. F. \& Timi, J. T. 1998. Parasite communities of Genypterus blacodes and G. brasiliensis (Pisces: Ophidiidae) from Argentina. Helminthologia 35:209.

SiQuier, G. F. \& OstrowsKi De NuÑEZ, M. 2009. Ligophorus uruguayense sp. nov. (Monogenea, Ancyrocephalidae), a gill parasite from Mugil platanus (Mugiliformes, Mugilidae) in Uruguay. Acta Parasitologica 54:95-102.

Suriano, D. M.; Çuburu, M. L. \& Labriola, J. B. 2000. Floridosentis mugilis (Machado Filho, 1951) (Acanthocephala: Neoechinorhynchidae) from Mugil platanus Günther, 1880 (Mugiliformes: Mugilidae) in San Clemente del Tuyu, Buenos Aires Province, Atlantic Coast, Argentina. Research and Reviews in Parasitology 60:107-112.

ViozZI, G. P. 1996. Presencia de protozoos parásitos en peces autóctonos de Patagonia Argentina. Boletín Chileno de Parasitología 51:32-34.

Zatti, S. A.; Naldonia, J.; Silvab, M.; Maiab, A. \& Adriano, E. A. 2015. Morphology, ultrastructure and phylogeny of Myxobolus curimatae n. sp. (Myxozoa: Myxosporea) a parasite of Prochilodus costatus (Teleostei: Prochilodontidae) from the São Francisco River, Brazil. Parasitology International 64(5):362-368. 